\title{
ASSESSMENT OF HEAVY METAL STATUS OF BOREHOLES IN CALABAR SOUTH LOCAL GOVERNMENT AREA, CROSS RIVER STATE, NIGERIA
}

Njar, G. N., ${ }^{*}$ Iwara, A.I., ${ }^{2}$ Offiong, R.A. ${ }^{1}$ and Deekor, T.D. ${ }^{3}$

DOI: http://dx.doi.org/10.4314/ejesm.v5i1.10

\begin{abstract}
Received 16th January 2012; accepted 13th February 2012

Although, many heavy metals are necessary in small amounts for the normal development of the biological cycles, most of them become toxic at high concentrations. The major sources of heavy metal pollution in urban areas of Nigeria are anthropogenic, while contamination from natural sources predominates in the rural areas. The study examined heavy metal status of boreholes in Calabar South, Cross River of Nigeria. Four functional boreholes in the area were sampled. Result showed that the concentrations of iron ( $\mathrm{Fe})$, zinc ( $\mathrm{Zn})$ and Manganese (Mn) were within WHO maximum permissible limit with mean values of $0.065 \mathrm{ml}^{-1} \mathrm{~g}, 0.015 \mathrm{mgl}^{-1}$ and $0.002 \mathrm{mgl}^{-1}$ respectively. The proportion of copper $(\mathrm{Cu})$, chromium $(\mathrm{Cr})$ and lead $(\mathrm{Pb})$ in the sampled boreholes was zero, indicating the absence of these metals in the sampled boreholes. The absolutely low levels of heavy metal contents across the sampled boreholes showed they were not polluted and as such suitable for human consumption. The low content also revealed that boreholes in the area were located far away from dumpsites; soak away pits, automobile shops and other forms of heavy metal contaminants. In order to maintain quality status of boreholes in the area, routine monitoring and assessment of boreholes mostly the indiscriminate sinking of boreholes in the area by sanitary inspection officers was suggested.
\end{abstract}

Keywords: Heavy Metal, Borehole Water, Functional Boreholes, Proportion, Quality Status

\section{Introduction}

Heavy metal is a generic term that describes the group of metals and metalloids with atomic density greater than $4 \mathrm{~g} / \mathrm{cm}^{3}$ or 5 times or more, greater than water. Heavy metal according to Duruibe et al., (2007) has little to do with density but concerns chemical properties. However, lead, cadmium, mercury and arsenic are main threats to human health when exposed to them. Mildvan (1970) noted that heavy metals such as $\mathrm{Cd}, \mathrm{Ni}, \mathrm{As}, \mathrm{Pb}$ pose a number of hazards to humans; and are indeed cofactors as activator biochemical reactions and enzymatic for information of enzyme/substrate metal complex. Heavy metals are natural components of the earth's crust, as can neither be degraded nor destroyed. Environmental pollution by heavy metals is prominent in mining and old mine sites and pollution reduces with increasing distance away from mining sites. Through mining activities, water bodies mostly surface water are most polluted (Garbarino et al., $1995)$ and the possibility of contamination

${ }^{1}$ Dept. of Geography \& Regional Planning, University of Calabar, Nigeria

${ }^{2}$ Dept. of Geography, University of Ibadan, Nigeria

${ }^{3}$ Dept. of Geography \& Environmental Management, 86

University of Port Harcourt Nigeria

*Corresponding author email:iwaradream2008@yahoo.com through erosion (Duruibe et al., 2007), and when mined ores are dumped on the earth surfaces in manual dressing processes. Through rivers and streams, the metals are transported as either dissolved species in water or as an integral part of suspended matter causing the most deleterious effects on aquatic life (Duruibe et al., 2007).

In addition, to a small extent, the metals enter the human bodies via food, drinking water and air. Though, some heavy metals (e.g. copper, selenium, zinc) are essential to maintain the metabolism of the human body, but, concentrations above the desirable level can lead to poisoning (Lenntech, 2011). Heavy metal poisoning could result, for instance, from drinking-water contamination (e.g. lead pipes), high ambient air concentrations near emission sources, or intake via the food chain. Heavy metals are dangerous because they tend to bioaccumulate. Bioaccumulation results when there is an increase in the concentration of a chemical in a biological organism over time, compared to the natural concentration of 
chemicals in the environment. Heavy metals may enter a water supply by industrial and household wastes, or from acidic rain resulting in the disintegration of soils and releasing heavy metals into streams, lakes, rivers, and groundwater (Lenntech, 2011).

Many trace elements are necessary in small amounts for the normal development of the biological cycles, but most of them become toxic at high concentrations. The major sources of heavy metal pollution in urban areas of Africa are anthropogenic, while contamination from natural sources predominates in the rural areas. Anthropogenic sources of pollution include those associated with fossil fuel and coal combustion, industrial effluents, solid waste disposal, and mining and metal processing. In animal body, metals enter through feeds, green fodder, drinking water and pharmaceuticals, consumption of mineral supplements with high content of trace metal and licking of painted surfaced containing metallic pigments (Raikwar et al., 2008). However, among these pathways, the atmosphere tends to be of greatest to human health, as a result of the quantities of contaminants involved and the widespread dispersion and exposure (Raikwar et al., 2008).

According to Olade (1987), the impact of these pollutants is confined mostly to the urban centres with large populations, high traffic density and consumer-oriented industries. Natural sources of pollution include weathering of mineral deposits, brush burning and windblown dusts. Among the heavy metals, the most serious effect of pollution is presently associated with lead $(\mathrm{Pb})$ emission (Olade, 1987). Heavy metals like Fe, $\mathrm{Cu}, \mathrm{Zn}, \mathrm{Ni}$ and other trace elements are important for proper functioning of biological systems and their deficiency or excess could lead to a number of disorders. Food chain contamination by heavy metals has become a serious issue in recent years because of their potential accumulation in biosystems through contaminated water, soil and air. Therefore, a better understanding of heavy metal sources, their accumulation in the soil and the effect of their presence in water, soil and on plant systems seem to be particularly important issues of present day research on risk assessment (Sharma et al., 2004). Calabar South Local Government Area of Cross River State, as an urban centre with relatively high population of 80, 196 persons (NPC, 2006; Ottong et al., 2010), commercial activities and service industries, the absence of potable water to every household has led to the proliferation of boreholes as a result of its high demand and lucrative nature. As such, in some areas, boreholes are located too near and downstream of soak away pits or adjoining landfills/waste dump sites (Afangideh et al., 2011).

The concentration of heavy metal in water sources (river, stream, well and boreholes) has attracted concerns from scholars, as a result of its health implications on biotic organisms especially man. The literature is exhaustive on the subject, and every study examined the level of these metals in water sources in their respective ecosystems (Olade, 1987; Jarup, 2003; Duruibe et al., 2007; Samudin et al., 2009; Prabu, 2009; Momodu and Anyakora, 2010; Nwankwoala et al., 2011). However, despite the abundance of literature on heavy metals, there is paucity of information on heavy metal status of boreholes in Calabar South Local Government Area. This study therefore attempts to assess the heavy metal status of boreholes in the area as well as discusses the health implications of consuming borehole water with high concentration of heavy metals.

\section{Material and methods \\ Study area}

The study was conducted in Calabar South Local Governments Area of Cross River State, Nigeria between the $3^{\text {rd }}$ and $7^{\text {th }}$ of September, 2009. Calabar South is located approximately between longitude $8^{0} 19^{\prime} \mathrm{E}$ and $8^{0} 21^{\prime} \mathrm{E}$ and latitude $4^{0} 55^{\prime} \mathrm{N}$ and $4^{0} 58^{\prime} \mathrm{N}$. Owing to it latitudinal location, the area receives abundant and constant insolation. The maximum temperature is above $27^{\circ} \mathrm{C}$ with a peak at about $35^{\circ} \mathrm{C}$ during January to February. The vegetation of Calabar South is characterized by mangrove and rainforest ecosystems which form part of the rich fauna 
and flora of the state. The major economic activities in the area are farming, fishing and the public sector which are basically government owned ministries. Presently, the pace is set to rejuvenate a dynamic, purposeful and vibrant sector economy in the metropolis to complement the tourism drive of the state (Afangideh et al., 2011). The major sources of water for drinking in the area are pipe-borne water, borehole, rainwater and river.

\section{Sample collection and analysis}

The procedure for data selection started with a reconnaissance survey to the area. This enabled functional boreholes to be identified. Functional borehole was conceptualized as one that is frequently in use with level of patronage (use) greater than 50 persons per day. Through this approach, 19 functional boreholes were identified, with their names written on pieces of paper after which 4 boreholes were randomly selected without replacement. Water samples were collected in 1.5 litre plastic bottles; before the collection of water samples, the boreholes were allowed to pump for 15 minutes so that water with a constant temperature and $\mathrm{pH}$, representing that from the aquifer was collected. Water samples were collected at the borehole heads. Prior to sample collection, all plastic bottles were rinsed thrice with the borehole water. After sampling, the containers were tightly covered. The samples were appropriately labeled and put in an ice-packed cooler, and immediately taken to the laboratory for analysis of heavy metals using flame atomic absorption spectrophotometer, AAS (model 210/211VGP); 220GF Graphite furnace 220 AS Autosampler. In addition, physical properties such as $\mathrm{pH}$, TSS, turbidity, conductivity and total hardness were determined using standard methods (APHA, 1998). Results obtained from the laboratory analysis were represented using tables and averages, while analysis of variance (ANOVA) for significant variation in water quality among the sampled boreholes was determined using SPSS 17.0 for Windows. The trace elements analysed were $\mathrm{Fe}, \mathrm{Mn}, \mathrm{Cu}$, $\mathrm{Zn}, \mathrm{Pb}$ and $\mathrm{Cr}$.

\section{Results and Discussion}

The physico-chemical parameters of water samples from the four boreholes shows that the borehole water samples are acidic with mean $\mathrm{pH}$ value of 5.56. The acidic nature of borehole water is attributed to the presence of tiny shale intercalations in the aquiferous coastal plain sand (Afangideh, et al., 2011). The $\mathrm{pH}$ values are below the minimum desirable limits of 6.5 set by WHO (WHO, 2006). The values of total suspended solids (TSS) and turbidity are zero; meaning that the water is harmless, in its natural state and ideal for human consumption. It further indicates the absence of organic and inorganic solids (Afangideh, et al., 2011). The conductivity of the borehole samples varied with a mean value of $357 \mu \mathrm{Scm}^{-1}$. This value is within WHO desirable limit of $500 \mu \mathrm{Scm}^{-1}$ for drinking water. However, total hardness of the water samples ranged from 16.00 to $32.00 \mathrm{mgl}^{-}$ ${ }^{1}$ with a mean value of $32.00 \mathrm{mgl}^{-1}$, and is below WHO $500 \mathrm{mgl}^{-1}$ acceptable limit, meaning the water is soft and foamy. This indicates that the boreholes are suitable for domestic consumption.

\section{Heavy metal analysis of the groundwater samples}

Table 2 shows vital information on the contents of heavy metals in the sampled boreholes. The concentration of iron $(\mathrm{Fe})$ in the borehole water ranged between 0.016 to $0.088 \mathrm{mgl}^{-1}$ with a mean value of $0.065 \mathrm{mgl}^{-1}$. $\mathrm{Fe}$ content in the sampled boreholes is with within WHO maximum permissible limit of $0.3 \mathrm{mgl}^{-1}$. The low concentration of $\mathrm{Fe}$ means water from these boreholes does not have the potentials of staining laundering as well as disrupt the human system. The value of manganese $(\mathrm{Mn})$ ranged from 0.002 to $0.003 \mathrm{mgl}^{-1}$ with a mean value of $0.002 \mathrm{mgl}^{-1}$; the mean content of $\mathrm{Mn}\left(0.001 \mathrm{mgl}^{-1}\right)$ falls within the maximum desirable limit of $0.5 \mathrm{mgl}^{-}$ ${ }^{1}$ set by WHO. The low concentration of Mn implies that water from the sampled boreholes has good taste and would not promote the growth of algae in reservoirs or collection tanks (Nwankwoala et al., 2011). Zinc is considered non-toxic, but excess amount can cause system dysfunctions that result in impairment of growth and reproduction 
(Nolan, 2003). The clinical signs of zinc have been reported to include vomiting, diarrhea, bloody urine, icterus (yellow mucus membrane), liver failure, kidney failure and anemia (Fosmire, 1990); Duruibe et al., 2007).

Zinc $(\mathrm{Zn})$ content in the borehole water samples ranged from 0.012 to $0.018 \mathrm{mgl}^{-1}$ with a mean value of $0.015 \mathrm{mgl}^{-1}$ is within WHO maximum allowable of $3.0 \mathrm{mgl}^{-1}$ for drinking water (table 2). This indicates that water from the sampled water contain the right proportion of $\mathrm{Zn}$ which is an essential plant and human nutrient element. The low concentration further implies the boreholes do not have caustic taste, hence ideal for consumption and other domestic uses. Lead is the most toxic of the heavy metals. Its inorganic forms are absorbed through ingestion by food, water and inhalation (Ferner, 2001). In humans exposure to lead can result in a wide range of biological effects depending on the level and duration of exposure. High levels of exposure may result in toxic biochemical effects in humans which in turn cause problems in the synthesis of haemoglobin, effects on the kidneys, gastrointestinal tract, joints and reproductive system, and acute or chronic damage to the nervous system (Lenntech, 2011; Duruibe et al., 2007). The proportion of lead (Pb) in the sampled boreholes was zero, indicating the absence of lead contamination. Copper is an essential substance to human life, but in high doses it can cause anemia, liver and kidney damage, and stomach and intestinal irritation.

Copper occurs in drinking water from copper pipes, as well as from additives designed to control algal growth. Just like $\mathrm{Pb}$, $\mathrm{Cu}$ and $\mathrm{Cr}$ were absent in the sampled boreholes. Chromium is used in metal alloys and pigments for paints, cement, paper, rubber, and other materials. Low-level exposure can irritate the skin and cause ulceration. Long-term exposure can cause kidney and liver damage, and damage too circulatory and nerve tissue. Chromium often accumulates in aquatic life, adding to the danger of eating fish that may have been exposed to high levels of chromium (Lenntech, 2011). The proportion of copper $(\mathrm{Cu})$, chromium $(\mathrm{Cr})$ and lead $(\mathrm{Pb})$ was zero, indicating the absence of these metals in the sampled boreholes (table 2). The ANOVA result shows that the contents of heavy metals do not vary significantly among the four boreholes $\left(\mathrm{F}_{3,20}=242, \mathrm{P}>0.05\right)$.

\section{Conclusion/Recommendations}

The absolutely low levels of heavy metal contents across the sampled boreholes show they are not polluted and as such suitable for human consumption. The low content also reveals that boreholes in the area are located far away from dumpsites, automobile shops and other forms of heavy metal contamination. The result therefore implies that the quality status of boreholes in the area is not in any way polluted, as the examined parameters are within WHO maximum permissible limits for drinking water. In order to maintain the present quality status of boreholes in the area, routine monitoring and assessment of boreholes mostly the indiscriminate sinking of boreholes to meet the ever increasing demands of people in the area by sanitary inspection officers is suggested.

\section{References}

Afangideh, A.I., Njar, G. N., Ewa, E. E., Eli, H.D. and Iwara, A. I. (2011) Assessment of Water Quality Status of Borehole in Calabar South Local Government Area, Cross River State. International Journal of Biosciences, 1 (5): $71-76$

Duruibe, J. O. Ogwuegbu, M. O. C. and Egwurugwu, J. N. (2007) Heavy Metal Pollution and Human Biotoxic Effects. International Journal of Physical Sciences, 2 (5): $112-118$

Ferner, D. J. (2001) Toxicity, Heavy Metals. eMed. J., 2(5): 1.

Fosmire, G. J. (1990) Zinc Toxicity. Am. J. Clin. Nutr., 51(2): 225 -227

Garbarino, J. R. Hayes, H. Roth, D. Antweider, R. Brinton, T. I. and Taylor, H. (1995) Contaminants in the Mississippi River, U. S. Geological Survey Circular 1133, Virginia, U.S.A. www.pubs.usgs.gov/circ/circ1133/ 
Lenntech (2011) Heavy Metals. http://www.lenntech.com/processes/heavy/hea vy-metals/heavy-metals.htm

Mildvan, A.S. (1970) Metals in Enzymes Catalysi, in D.D., Boyer (ed) The Enzymes, Academic Press, London. pp 445-536

Momodu, M. A. and Anyakora, C.A. (2010) Heavy Metal Contamination of Ground Water: The Surulere Case Study. Research Journal Environmental and Earth Sciences, 2(1): 39-43

National Population Commission (2006) Population and Housing Census of the Federal Republic of Nigeria, Cross River State Priority Tables, Volume 1.

Nwankwoala, H. O., Udom, G. J. and Ugwu, S. A. (2011) Some Heavy Metal Investigations in Groundwater Sources in Yenagoa, Bayelsa State, Nigeria. Journal of Applied Technology in Environmental Sanitation, 1 (2): 163-170

Olade, M. A. (1987) Heavy Metal Pollution and the Need for Monitoring: Illustrated for Developing Countries in West Africa in T. C. Hutchinson and K. M. Meema (eds) Lead, Mercury, Cadmium and Arsenic in the Environment. SCOPE: John Wiley \& Sons Ltd
Ottong, J. G., Ering, S. O., and Akpan, F. U. (2010) The Population Situation in Cross River State of Nigeria and Its Implication for Socio-Economic Development: Observations from the 1991 and 2006 Censuses. Journal of Emerging Trends in Educational Research and Policy Studies, 1 (1): 36-42

Prabu, P.C. (2009) Impact of Heavy Metal Contamination of Akaki River of Ethiopia on Soil and Metal Toxicity on Cultivated Vegetable Crops. EJEAF Che, 8 (9): 818-827

Raikwar, M. K., Kumar, P., Singh, M. and Singh, A. (2008) Toxic Effect of Heavy Metals in Livestock Health. Veterinary World, 1(1): 28-30

Sharma, R., Agarwal, M. and Marshall, F.M. (2004) Effects of Waste Water Irrigation on Heavy Metal Accumulation in Soil and Plants. Paper presented at a National seminar, Bangalore University, Bangalore, Abst.no.7, p.8

World Health Organization (WHO) (2004) Guidelines for Drinking Water Quality: Incorporating 1st and 2nd Addlenda, Vol.1 World Health Organization WHO (2006) Guideline for Drinking Water Quality. Vol. Recommendations, World Health Organization, Geneva, pp: 130

Table 1 Physico-chemical parameters of borehole water samples

\begin{tabular}{|l|c|c|c|c|}
\hline \multirow{2}{*}{ Parameters } & \multicolumn{2}{|c|}{ Range } & \multirow{2}{*}{ Mean values } & \multirow{2}{*}{ WHO* } \\
\cline { 2 - 3 } & Min & Max & & \\
\hline $\mathrm{pH}$ & 5.46 & 5.62 & 5.62 & $6.5-8.5$ \\
\hline TSS $\left(\mathrm{mgl}^{-1}\right)$ & 0.00 & 0.00 & 0.00 & - \\
\hline Turbidity $(\mathrm{FTU})$ & 0.00 & 0.00 & 0.00 & 5 \\
\hline Conductivity $\left(\mu \mathrm{Scm}^{-1}\right)$ & 190 & 494 & 357 & 500 \\
\hline Total Hardness $\left(\mathrm{mgl}^{-1}\right)$ & 16.00 & 32.00 & 32.0 & 500 \\
\hline
\end{tabular}

*WHO (2004: 2006) 
Table 2 Heavy metal concentrations of borehole water samples

\begin{tabular}{|c|c|c|c|c|c|c|}
\hline \multirow{2}{*}{\multicolumn{2}{|c|}{ Parameters }} & \multicolumn{2}{|c|}{ Range } & \multirow{2}{*}{ Mean } & \multirow{2}{*}{\multicolumn{2}{|c|}{$\begin{array}{l}\text { Max. acceptable limit } \\
(\mathrm{WHO})^{*}\end{array}$}} \\
\hline & & $\operatorname{Max}$ & Min & & & \\
\hline \multicolumn{2}{|l|}{ Iron $(\mathrm{Fe}) \mathrm{mgl}^{-1}$} & 0.088 & 0.016 & 0.065 & & 0.3 \\
\hline \multicolumn{2}{|c|}{ Manganese $(\mathrm{Mn}) \mathrm{mgl}^{-1}$} & 0.003 & 0.002 & 0.002 & & 0.5 \\
\hline \multicolumn{2}{|c|}{ Copper $(\mathrm{Cu}) \mathrm{mgl}^{-1}$} & 0.00 & 0.00 & 0.00 & & 2.0 \\
\hline \multicolumn{2}{|c|}{ Zinc $(\mathrm{Zn}) \mathrm{mgl}^{-1}$} & 0.018 & 0.012 & 0.014 & & 3.0 \\
\hline \multicolumn{2}{|l|}{ Lead $(\mathrm{Pb})$} & 0.001 & 0.002 & 0.001 & & 0.01 \\
\hline \multicolumn{2}{|c|}{ 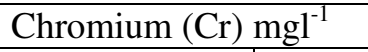 } & 0.000 & 0.000 & 0.000 & & 0.05 \\
\hline \multirow{2}{*}{ Parameters } & \multicolumn{6}{|c|}{ Selected boreholes } \\
\hline & \multicolumn{2}{|c|}{ Goldie } & Harcourt & \multicolumn{2}{|c|}{ Atamuno } & Palm Street \\
\hline $\mathrm{Fe}\left(\mathrm{mgl}^{-1}\right)$ & \multicolumn{2}{|c|}{0.088} & 0.073 & \multicolumn{2}{|c|}{0.016} & 0.082 \\
\hline $\mathrm{Mn}\left(\mathrm{mgl}^{-1}\right)$ & \multicolumn{2}{|c|}{0.002} & 0.003 & \multicolumn{2}{|c|}{0.001} & 0.002 \\
\hline $\mathrm{Cu}\left(\mathrm{mgl}^{-1}\right)$ & \multicolumn{2}{|c|}{0.000} & 0.000 & \multicolumn{2}{|c|}{0.000} & 0.000 \\
\hline $\mathrm{Zn}\left(\mathrm{mgl}^{-1}\right)$ & \multicolumn{2}{|c|}{0.018} & 0.012 & \multicolumn{2}{|c|}{0.014} & 0.011 \\
\hline $\mathrm{Pb}\left(\mathrm{mgl}^{-1}\right)$ & \multicolumn{2}{|c|}{0.000} & 0.000 & \multicolumn{2}{|c|}{0.000} & 0.000 \\
\hline $\mathrm{Cr}\left(\mathrm{mgl}^{-1}\right)$ & \multicolumn{2}{|c|}{0.000} & 0.000 & \multicolumn{2}{|c|}{0.000} & 0.000 \\
\hline
\end{tabular}

*WHO (2004) 